I employ Cornelius Van Til's theistic or Christian philosophy in this thesis to examine the capital and interest theories of the Austrians. This is achieved by assessing the development of the Austrian School, its methodology (as represented in the epistemology and ontology of each of the Austrian scholars), the founding capital and interest work of Menger, and the subsequent contributions made by Böhm-Bawerk, Hayek, and Mises.

My claim in the thesis is that the Austrians argue for an ontology and an epistemology that have allowed them to develop unique theorems in economics, but that, from Van Til's theistic perspective, these theoretical propositions are claims that cannot be justified by the Austrians.

Furthermore, I argue that the capital theory and the interest theory of Mises are those central to the continuing Austrian School. Mises' praxeology is an epistemology developed along the lines of a monistic ontology. However, I claim that Mises did not provide a sound rationale for the important matters of the uniformity of nature, the law of cause and effect, or the logical structure of the human mind; therefore, Mises (and the Austrians) can provide no solution to the philosophical problem of the one-over-many. Mises also asserts that the mind-matter, or subject-object, relation exists; I argue that Mises does not present a sound argument for this proposition but just assumes that it exists.

I argue that Van Til's ontology and epistemology provide an answer to these crucial philosophical issues but that the Austrians cannot. This means that the Austrians' economic theorems, particularly those of Mises, do not possess a sound foundation; therefore, their claims to knowledge or truth for their theories of capital and interest are also not able to be justified.

The focus of my thesis is the ontological and epistemological groundwork of the Austrian School as it has an impact on the important areas of capital theory and interest theory. However, though I conclude that the Austrians cannot justify the groundwork of their position, this conclusion does not deny the importance of their valuable contributions to capital theory and interest theory.

\title{
REGULATIONS AND COMPETITION IN THE FRENCH RAILROAD INDUSTRY 1823-1914
}

\section{GUY NUMA*}

\author{
Supervisor: Prof. François Etner \\ University: Université Paris-Dauphine (LEDa-SDFi) \\ Date of Graduation: December 2009 \\ Language: French
}

January 1, 2010, marks the beginning of competition for the international traffic of passengers in the European Union. This deadline raises the problem of the regulation

\footnotetext{
*Assistant Professor, Université de Picardie Jules Verne, C.R.I.I.S.E.A., Amiens, France. email: guy.numa@dauphine.fr.
} 
of the railroad industry and underlines the relevance of studying the interplay between economic analysis, the development of the current events, and the evolution of legislation. From an historical and comparative perspective, I examine the economic theories that justify how competition is practiced. Studying how the railroad industry was regulated in the nineteenth century, I unveil how economic analysis influenced legislation, and, reciprocally, how the legislation stimulated the work of the theorists. Thus, I shed light on the similarities in the regulations of the railroad industry in the nineteenth and twentieth centuries on three points: vertical unbundling; potential competition; and price cap. First, I retrace the origins of the concession that was the main regulation method, analyzing the theoretical oppositions between the theorists about the way the concessions were granted and how they functioned. Secondly, I analyze the intramodal competition by comparing the regulation theories and practices in France, Great Britain, and the US. Finally, I show that the competition between the inland waterways and the railroads constitutes a form of intermodal competition, which failed to mitigate the growth of the railroad companies.

This research allows me to conclude that: 1 . There was no univocal relationship between economic theory and legislation. One the one hand, the former influenced the latter, and on the other hand, economic theory and legislation relied on the facts. 2. As a field of observation, the railroads have brought significant contributions to the economic analysis. To better understand it, one must imagine how the world would be without this great invention. Economists would have solved with more difficulty issues related to costs, price discrimination, and efficacy of public utilities management overall. 3. The scrutiny of the facts and debates regarding the railroads sheds light on a Marshallian conception of competition, which entails cooperation between producers and a form of state interference. We are far from a notion of competition, which means a non-cooperative rivalry of the agents on the market.

Below I outline three papers derived from the thesis that are already published or accepted for publication.

\section{DUPUIT AND WALRAS ON THE NATURAL MONOPOLY IN TRANSPORTATION INDUSTRIES: WHAT THEY REALLY WROTE AND MEANT (NUMA 2011)}

In this article, I analyze and compare the contributions of Dupuit and Walras on the natural monopoly of railroads. Both theorists argued that railroads-as opposed to inland waterways - could not be vertically unbundled, a point that previous authors who compared their views failed to point out. Moreover, until now, Dupuit's analysis of the railroad monopolies before the Société d'Economie Politique has been overlooked. This article fills this gap in the literature by showing that Dupuit and Walras both concluded that railroads were better managed under the monopoly regime; however, they drew upon different perspectives. I argue that Dupuit was more pragmatic, using the concept of "de facto monopoly," while Walras was more ideological, arguing that the railroad industry was a public utility. In so doing, I 
underline that Dupuit did not oppose government intervention, counter to a few misrepresentations and fallacies in the literature.

\section{MILL ON THE NATURAL AND PRACTICAL MONOPOLY (NUMA 2010)}

J.S. Mill is generally considered to be the theorist who gave birth to the concept of natural monopoly in its modern sense. Yet, no author has specified that Mill distinguishes two types of monopoly, the "natural monopoly" and the "practical monopoly." I show that Mill's notion of "practical monopoly" appears to describe the contemporary meaning of natural monopoly. However, both notions have a common thread: they signify the benefits of occupying a privileged or strategic position.

\section{AGENCY THEORY AND FRENCH RAILROAD CONCESSIONS (NUMA 2009)}

From the seminal contribution of Jensen and Meckling (1976) ${ }^{1}$ to the more recent work of Laffont and Martimort (2002), ${ }^{2}$ the principal-agent model has been used in a broad range of fields over the last thirty years. Yet, no previous study has examined the case of railroad concessions in the nineteenth century as an example of a principal-agent relationship. I show that one of the main assumptions of this theory - the asymmetric information at the benefit of the agent-is not verified in these types of concessions. I also present a new approach by defining the interest guarantee as a specific type of risk sharing that diminishes the effort incentive. While the principal-agent model predicts increased effort on the part of the agent under conditions of risk sharing, I demonstrate that railroad companies made less effort to efficiently manage their operations. Therefore, I suggest that agency theory does not account for the efficiency and the function of nineteenth-century railroad concessions.

\section{REFERENCES}

Numa, Guy. 2011. "Dupuit and Walras on the Natural Monopoly in Transport Industries: What They Really Wrote and Meant." History of Political Economy 43 (4): forthcoming. See: http://ssrn.com/ abstract $=1525366$.

Numa, Guy. 2010. "Note sur le monopole naturel et le monopole pratique chez J.S. Mill." Revue économique 61 (2): 341-352.

Numa, Guy. 2009. "Théorie de l'agence et concessions de chemins de fer français au $19^{\mathrm{e}}$ siècle." Revue d'économie industrielle 125: 105-128.

\footnotetext{
${ }^{1}$ Jensen Michael, and Willaim Meckling. 1976. "Theory of the Firm: Managerial Behavior, Agency Costs and Ownership Structure.” Journal of Financial Economics 3 (4): 305-360.

${ }^{2}$ Laffont Jean-Jacques, and David Martimort. 2002. The Theory of Incentives: the Principal-Agent Model. Princeton and Oxford: Princeton University Press.
} 